\title{
Economic Empowerment Model for the Poor Through Zakat Institution Under Maqashid Syariah Concept in West Kalimantan
}

\author{
Sukma Indra ${ }^{1}$ \\ ${ }^{1}$ Tanjungpura University, Pontianak, Indonesia \\ Correspondence: Dr. Sukma Indra, S. E., M. M., Tanjungpura University, Pontianak, Indonesia.
}

Received: February 8, 2018

Accepted: March 6, 2018

Online Published: March 12, 2018

doi:10.20849/ajsss.v3i1.337

URL: https://doi.org/10.20849/ajsss.v3i1.337

\begin{abstract}
This research aimed at finding out the distribution of zakat and obstacles faced by BAZNAS West Kalimantan Province in economic empowerment for the poor. The research employed field research. After data collection done, the analysis carried out by doing Focus Group Discussion (FGD) to formulate maqāsid al-syari'ah based model of economic empowerment for the poor through BAZNAS West Kalimantan Province. The formulated model is able to be used as alternative for BAZNAS West Kalimantan Province in conducting maqāsid al-syari'ah based model of economic empowerment for the poor, especially in West Kalimantan.
\end{abstract}

Keywords: Zakat, Maqashid Syariah, economic empowerment, BAZNAS

\section{Introduction}

Islam is the religion that grants a mercy to all creation as it regulates all aspect of human's life thoroughly including the poverty issue. The seriousness of Islam in making efforts for poverty alleviation is a mandatory as zakat is the third pillar of Islam after the confession of faith and Salat.

Currently, the poverty rate in West Kalimantan Province is quite high. According to data released by Central Bureau of Statistic of West Kalimantan up to September 2015, the poverty rate was 405.510 people or about 8.44\%. Furthermore, it explained that from March to September 2015, the percentage of poor people in West Kalimantan was increased in urban and rural areas. The percentage of poor people in urban areas was 5.62 increased to $6.00 \%$. Meanwhile, it was also increased in rural areas, from $9.09 \%$ into $9.51 \%$ (pontianak.tribunnews.com).

The slightly high poverty rate in West Kalimantan Province becomes Islam's concern. This is because Islam is a universal religion which has tenets governing people's behaviours, it regulates the relationship of human being with his God (ubudiyah) or among human beings (mu'amalah). The economic activity is one of relationship forms amongst human being that should always contain divine values, and should be leaned on Islam's tenets particularly Islam economic system accentuating the value of justice and balance for success, happiness and well-being (Falah).

In order to realize the purpose of islamic economic, thus muslims aspire to have organized economic system to assure the system of wealth distribution is well organized. The main principle that determines the wealth distribution is justice and affection. There are two objectives of distribution. First, to make sure that the wealth does not stockpile on a small group of people, but it should be evenly distributed to people. Second, various factors of existing production should be distributed fairly for the prosperity of the country (Afzalur Rahman, 1995).

One of muamalah (commercial and civil acts or dealings under Islamic law) activities that has an important role in distributing wealth in Islam is zakat, infaq and shadaqah. Zakatis a significant instrument to uphold economic equity of society. It does not only aim to help the poor, but also to provide more permanent objectives, particularly for economic empowerment, economic strengthening of mustahiq until poverty alleviation. Zakat is expected to minimize inequality of income distribution in the society, accordingly no more mustahiq. It can be realized by the compliance of basic needs of mustahiq, as well as the improvement of income distribution till mustahiq becomes muzakki (Adiwarman Karim, 2010).

According to Rahmah Yulisa Kalbarini and Tika Widiastuti (2016), the potency of Zakat in West Kalimantan in 2011 reached 1.2 trillion. Zakat collected by the National Board of Zakat (Baznas) in West Kalimantan Province 
in 2011 was 1,626 billion. In 2016, Zakatcollected by Baznas West Kalimantan Province significantly increased to 3.6 billion.

The increase of funds by Baznas West Kalimantan Province is not generating the decrease of poverty rate in West Kalimantan as initially explained. Therefore, the writer deduces that one of solutions to address the main problem of poverty alleviation and efforts bridging the gap between the rich and the poor is by strengthening the empowerment of zakatproductively. The empowerment of zakat is implemented by firstly improving the understanding of theoretic and operational concepts to improve the implementation and practice of zakat.

To improve the empowerment of zakatproductively especially in Pontianak of West Kalimantan, a model of economic empowerment for the poor under zakat institution by using maqashid syariah concept is deemed necessary in order to find alternative proper solution. In addition, the research and development on zakat institution and its management is still really deficient, even though it is greatly important in improving people's prosperity in West Kalimantan. In relation to aforementioned explanation, the researcher believes that it is important to conduct in-depth analysis in the research entitled "Economic Empowerment Model for the Poor through Zakat Institution under Maqashid Syariah Concept in West Kalimantan."

\section{Literature Review}

Any muslim who possesses the required amount of wealth is obliged to help the poor (Al-Isra' [17]: 26). In addition to consumptive aid, the empowerment of the poor is a necessary assistance. The aids given to the poor are business capital, training for skill development, and so forth. It is aimed at improving the poor's living standard and their family welfare. According to Islamic thought, a strong muslim is the most primary than a weak one (HR. Muslim, No. 2664). Strong means that it can be measured from the prosperity level.

The aids given to the poor are the collected zakat taken from people who are required by Allah to purify it (At-Taubah [9]: 103). The amount of the obligatory zakat in Indonesia encourages the establishment of an institution to accommodate zakat and distribute it to the right people. The institution is the National Board of Zakat (Baznas) which is the only official institution established by the Government under The Decree of President of Republic of Indonesia number 8 of 2001 and strengthened by Law number 23 of 2011 on Zakat Management. Baznas is also spread in every province of Indonesia, one of them is Baznas of West Kalimantan Province

Initially, BAZNAS has duty and function to collect Zakat, Infaq and Alms (ZIS), and distribute it consumptively afterward. This concept did not solve the problem dealt by mustahik, since it only solved the problem temporarily. Therefore, a concept of zakat distribution which empowers the poor is needed. In other words, zakat is not immediately exhausted, or it is not only fulfilling the poor's temporary needs, but it should also be able to provide productive empowerment. The hope is after the poor received zakat for productive purpose, for example business capital, they who were people accepting zakat (mustahik) will become people who give zakat (muzakki).

This is what the writer means with the concept of maqashid syariah in distributing zakat. The advantage of zakat distribution is not only for certain poor people who annually receive zakat (temporary mustahik), but it also has a wider advantage as it is able to reach another poor people. Therefore, the objective of Muslim's zakat obligation can be realized by using the concept of maqashid syariah in distributing zakat

According to Central Bureau of Statistic of West Kalimantan, the poverty rate in West Kalimantan on March 2017 decreased to 0,74\%(http://pontianak.tribunnews.com/2017/07/17). It indicates that the concept of maqashid syariahin distributing zakat by Baznas West Kalimantan has an impact. In spite of the fact that zakat distribution under the concept of maqashid syariah by Baznas is not the only factor that decreases the poverty rate in West Kalimantan.

Literally (lughawi), maqāsid al-syari'ah (Asmawi, 2012) consists of two words, they are maqāsid and syari'ah. Maqāsid is the plural noun of maqsid, which means 'deliberate action' or 'purpose'. From the root of language (Ahsan Lihasanah, 2008), maqāsid comes from the word قصد - يقصد - قصدا ' which means 'strong desire', 'cling firmly' and 'deliberately', or it can be defined (Mahmud Yunus, 1990) as 'deliberately' or 'intend to' (qashada ilaihi). Meanwhile, Yusuf Al-Qardhawi (2007) said that syari'ah comes from syara'a al-syai' which means 'explaining something', or taken from al-syar'ah andal-syari'ah that has meaning 'area of water source which is never dried and people who go there do not need tool', or 'the source of water'.

In addition, the root of al-syari'ah (Hasbi Umar, 2007) from the word شرع - يشرع - شرعا which means 'begin the implementation of a work'. According to Syamsul Anwar (2013), maqāsid al-syari'ahcan be defined asillah (illah faailiyyah), hikmah, andal-hadforal-ghayyah. Generally, Muslim theologians define maqāsid 
al-syari'ahbyseeing the meaning within the entire or most of Shari'a/Islamic law (al-ma'ani allati tulaahzhu $f i$ jami'in au muazzami al-ahkaami al-syariati). According to Al-Syathibi (2003), maqāsid al-syari'ah is the purposes and mysteries of Allah contained within every law for the purpose of fulfilling people's needs. In other words, the purpose of Allah in setting Shari'a is for people's benefits in the world and hereafter.

The integration between need, sufficiency and comfort should be referred to Shari'a (Writer Team at UII, 2012). It is clearly explained by many islamic law experts from time to time, such as Al-Ghazali, Al-Syathibi and many other figures. According to Al-Ghazali (1058-1111M), welfare (maslahah) of a society depends on the pursuit and maintenance of five basic purposes: protecting the religion (al-dien), life and soul (nafs), and intellect or mind (aql), family or ancestry (nasl) and treasure or wealth (maal). Likewise, Al-Syathibi (1388 M) also suggested similar opinion, he said that people's benefits can be realized if five fundamental elements of people's life can be maintained (Adiwarman Azwar Karim, 2010).

If the experts of Islamic jurisprudence (Fiqh) has formulated their primary needs in their day known in al-kuliyyah al-khamsah, then contemporary Muslim theologians (Muhammad al-Ghazali, Ahmad al-Khamlisyi, Yusuf al-Qardhawi, Ahmad al-Raisuni, Isma'il al- Hasani, and so forth) recommended that justice, egalitarian, freedom, social right, economic and political rights (al-'adl, al-musawat, al-hurriyat, al-huquq al-ijtima'iyah, wa al-iqtsadiyah wa al-siyasah) become the highest purpose of Shari'a.

The potency of zakat in Indonesia has not been developed optimally and professionally to date because of the ineffective institution in the collection, administration, distribution, monitoring and evaluation (Septiansyah, 2012). In other words, organizational system and zakat management so far are still classic, consumptive and inefficient which produce less social impact. Therefore, the writer expects a renewal or revision of the economic empowerment model for the poor through zakat institution by applying maqashid syariah concept for people's prosperity.

\section{Research Method}

The writer employed field research as the type of research; it means that the data refers to facts found in the field (Iqbal Hasan, 2002). This research employed qualitative research approach, in which the collected data will be described, produced and analyzed descriptively. It has a purpose to find out economic empowerment model for poor people through zakat institution with effective concept of maqashid syariah in West Kalimantan.

Qualitative approach is a research focusing on process; it does not make the research result as the orientation of success, but as the verification of hypothesis presenting the research results of existing social phenomenon. Yin (2009) stated that qualitative approach is an approach that employs data from written or spoken sources, phenomenon, knowledge or descriptive study. The research activity focused on finding obstacles of Baznas West Kalimantan and the economic empowermentmodel for the poor.

The research employed two techniques of data collection, they are depth interview, documentation and discussion in Focus Group Discussion (FGD) with Baznas West Kalimantan, MUI, academics as well as the relevant agencies specifically focused on economic empowerment for the poor. Interview was to collect data and information, evaluate or review the economic empowerment model for the poor, and to gain suggestion or recommendation from the administrator of Baznas for accomplishing the empowerment model.

The collected data was afterward analyzed. The data analysis was directed to socialization and finalization of the economic empowerment model for the poor through zakat institution under maqashid syariah concept. The socialization of model design was implemented through in-depth FGD, followed by the finalization of model.

Furthermore, maqashid syariah concept is the concept used in this research. It is deemed to be appropriate as analysis tool since the essential purpose of Islamic law is for people's benefits including shari'a on zakat. By using maqashidsyariahtheory, zakat is expected to address social and economic issues including poverty issue in West Kalimantan, and it is able to provide prosperity for people.

\section{The Economic Empowerment for the Poor in West Kalimantan}

Generally, the distribution of funding by Baznas West Kalimantan consists of two types; they are consumptive and productive distributions.

First, the consumptive distribution of zakatis a strong paradigm in Muslim's thought thatzakatshould be entirely distributed to all Mustahiq as explained in At-Taubah verse 60 (Junaidi Abdillah, 2014: 28). The real impact of this paradigm is zakat only has a role to improve momentary consumption for Mustahiq.

Second, the productive distribution of zakat is given to the poor, such as venture capital or others for productive business with a view to improve their standard of living. A Mustahiq is expected to be Muzakki (the one who 
pays zakat) in the future with a note that he/she is able to use the zakat for business (Nur Wahyudi dan Ubaidillah, 2015: 26). The program held by Baznas West Kalimantan in the productive distribution of zakat is scholarship from elementary to University levels, capital for small businesses and zakat community development (ZCD) for poor villages.

The program of venture capital is capital for small businesses by Baznas West Kalimantan Province to buy necessary tools for developing one's own business. Usually, the program reaches 150-200 people, in which Rp. $1,000,000 /$ person. By having this program, the poor is no longer be mustahiq at least next year, but they will be muzakki. Therefore, the business proposal must be proved by the reference of the Neighborhood Association and Headman explaining that the applicant is a poor man who has business.

Furthermore, ZCD for poor village program is a kind of pilot village. In doing this program, Baznas West Kalimantan Province considers that their urgent need and potency that can be developed in the village. In Irak village of Sajad Subdistrict of Sambas District, for example, Baznas West Kalimantan Province distributed zakat funds for goat farms, Sambas's weaving and water ambulance. This program cooperated and gathered the relevant agencies working on the village.

Zakat which was collected by Baznas West Kalimantan Province in 2016 was Rp. 3,340,232,014. It is about Rp. $1,937,334,568$ or $58 \%$ allocated to the indigent and the poor. Meanwhile, the rest was allocated to Amilin for Rp. 417,529,001 or $12.5 \%$, one who converts to Islam (Mualaf) for Rp. 167,011,600 or 5\%, Riqab for Rp. $83,505,800$ or $2.5 \%$, Ghariminfor Rp. $83,505,800$ or $2.5 \%$, Sabilillahfor Rp. $567,839,442$ or $17.5 \%$, and Ibnu Sabil for Rp. $83,505,800$ or $2.5 \%$.

Zakat allocated to the indigent and the poor for Rp. 1,937,334,568or 58\%, then realized into thirteen programs which broadly divided into two: distribution of consumptive zakat, and distribution of productive zakat. The distribution of consumptive zakat consists of seven programs, they are consumptive aid for dhuafa was Rp. 94,519,000, orphanage was Rp. 71,500,000, renovation for dhuafa's houses was Rp. 420,000,000, Ramadhan's activity was Rp. 60,000,000, medical assistance for dhuafa was Rp. 50,000,000, emergency responce was Rp. 473,151,318, and distribution through UPZ of Masjid Raya Mujahidin for Rp. 133,164,250. The total distribution of consumptive zakat was 1,302,334,568.

Distribution of productive zakat was relatively smaller than the consumptive one, about Rp. 635,000,000. The fund distributed in three programs: the scholarship program, capital for small businesses and ZCD program for poor village. The scholarship program for elementary students was Rp. 50,000,000; junior high school was Rp. 60,000,000; senior high school was Rp. 100,000,000, and; University was Rp. 200,000,000; meanwhile, the capital for small business was Rp. 150,000,000, and ZCD program for poor village was Rp. 75,000,000.

The writer, however, concluded that the aforementioned scholarship program from elementary to university levels is actually not included in productive zakat category, but it is the distribution of creative consumptive zakat. The opinion is supported by the category of zakat distribution of Junaidi Abdillah (2014: 29) explaining four patterns in distributing zakat: traditional consumptive distribution, creative consumptive distribution, traditional productive distribution, and creative productive distribution. Accordingly, capital for small business and ZCD for poor villages belong to distribution of traditional productive zakat.

Besides, funding allocation and distribution of productive zakat should be more developed and maintained seriously by Baznas West Kalimantan Province. It is expected that mustahik this year no longer becomes mustahik in the following year. By having productive zakat, mustahik are able to gain funds for developing their productive businesses which will improve their standard of living. The purpose is mustahik can be muzakki if they are able to use zakat for their business. Prophet Muhammad himself once did this, he gave his zakat for his friend's venture capital (Nur Wahyudi dan Ubaidillah, 2015: 26).

\section{Obstacles of Economic Empowerment for the Poor}

\subsection{Lack of Collected Zakat Funds}

Zakat funds collected by Baznas West Kalimantan Province in 2016 was increased from 2015, about 20\%. The Chairman of Baznas West Kalimantan Province, Didik Imam Wahyudi (2017: 12) stated that "in 2015, the acquisition of funds was Rp. 3.000.424.315, and total of funds in 2016 was Rp. 3.629.377.849, there is an increase about 20 percent."

In spite of the fact that zakat collected by Baznas West Kalimantan Province in 2016 has an increase of $20 \%$ from 2015, the figure has not reached 20\% of zakat potency in West Kalimantan. According to M. Basri Har, the potency of zakat that can be collected by Baznas West Kalimantan Province is about 20 billion. Therefore, mustahik that can be supported by Baznas West Kalimantan Province is not optimum. If the collected zakat was 
in accordance with the potency of zakat in West Kalimantan, then automatically mustahik would be supported optimally. Baznas West Kalimantan Province, however, adjusts zakat they have collected to be distributed to mustahik.

\subsection{Lack of Operational Funds}

The operational funds of Baznas West Kalimantan Province come from the collected zakat every year. If it accords with the potency, then the operational funds of Baznas West Kalimantan Province will be considerable. Otherwise, if it slightly discords with the potency, thus Baznas West Kalimantan Province only has little operational funds. It is because the operational funds of Baznas taken from 7,5\% of total funds of Baznas West Kalimantan Province annually.

Operational funds of Baznas West Kalimantan Province taken from 12,5\% of Amil rights from the collected zakat annually. $12,5 \%$ of the collected zakat then divided into two: 7,5\% allocated for Amil of UPZ at Agency/Institution and Task Force, while the rest 5\% allocated for the operational activity of Baznas West Kalimantan Province. In 2016, zakat collected by Baznas West Kalimantan Province was Rp. 3,340,232,014. Therefore, 12,5\% of Rp. 3,340,232,014. was about Rp. 417,529,001. The funds Rp. 417,529,001 was divided for two purposes, 7,5\% allocated for Amil of UPZ at Agency/Institution and Task Force was Rp. 250,517,401, while the rest 5\% allocated for the operational activity of Baznas West Kalimantan Province was Rp. 167,011,600..

The fund Rp. 167,011,600 was used for the operational needs of Baznas West Kalimantan Province in a year. It actually was a minimum amount to be allocated for the employees' salary, implementation of scheduled programs and other annual activities of Baznas. Therefore, lack of operational funds become one of obstacles of Baznas in doing the economic empowerment for the poor, especially in West Kalimantan Province.

\subsection{Lack of Human Resources}

Lack of human resources in Baznas West Kalimantan Province is also another obstacle faced by Baznas West Kalimantan Province in doing the economic empowerment for the poor, besides lack of operational funds.

The obstacles of Baznas West Kalimantan Province including lack operational funds and lack of quantity of human resouces are related to each other. It is because to recruit human resources in large quantity, funds for paying the employees' rights (salary) should be fulfilled.

\subsection{Lack of Endorsement from the Relevant Agency}

Baznas West Kalimantan Province requiring human resources, as it is a non-structural government institution which is independent and responsible to the President of Republic of Indonesia, concerns with the economic empowerment for the poor. Zakat collected then allocated mostly for the indigent and the poor out of another eight asnaf. Of total zakat collected by Baznas West Kalimantan Province in 2016, 58\% was allocated for empowering the economy of poor people.

Zakat then realized into thirteen programs broadly divided into two distributions: consumptive zakat distribution and productive zakat distribution. One of productive programs from Baznas West Kalimantan Province is ZCD program for poor village.

ZCD program for poor village is a kind of pilot village. In doing this program, Baznas West Kalimantan Province considers that their urgent need and potency that can be developed in the village. In Irak village of Sajad Subdistrict of Sambas District, for example, Baznas West Kalimantan Province distributed zakat fund for goat farms, Sambas's weaving and water ambulance. This program cooperated and gathered the relevant agencies working on the village.

After implementing this program for four years, Baznas West Kalimantan Province still has not attained optimum endorsement from the relevant agencies. According to M. Basri Har, this program is actually aimed at gathering local agency in each area to develop the potency of village which accords with their roles. "For example the agricultural agency. What can be helped to implement this program? What activity that has not been running or not optimal yet? Endorsement from the agency has not been appeared. It is Baznas West Kalimantan Province that completely empowers the poor people in the village," he said.

\section{Maqāsid Syariah Based Model of Economic Empowerment for the Poor}

Islamic law has vision to realize people's benefits (al-maslahah), in the world or hereafter. In order to realize the vision, Muslim theologians and fuqaha have formulated six missions of Islamic law known with al-dlaruriyat al-khamsah, they are: the obligation to protect the religion (hifzh al-din), to take care of mind (hifzh al-'aql), to maintain dignity and heredity (hizh al-nasl wa al- 'irdl) (Junaidi Abdillah, 2014: 24). 
As one of pillars and social regulation in Islam, zakat is not only vertical dimension of worship (hablun min Allāh) or ritual obligation, but also horizontal dimension (hablun min al-nās) that touches moral, social and economic dimensions. In horizontal dimension, according to Junaidi Abdillah (2014: 24), zakat is charity aspect that has a significant role as one of instruments in empowering people as well as poverty alleviation. Zakat is recognized to contribute greatly in influencing national economy on a macro basis, regardless of the failure of capitalist economy in realizing the purpose. Even more than that, zakat is a part of basic economic system in Islam that can be alternative system for world economy.

However, things which are believed and expected from the purpose and advantages of zakat distribution in reality has not be realized optimally. One of factors influencing ineffective use of zakat is the paradigm of zakat distribution in consumptive manner is entrenched in Muslims' minds that zakat should be entirely distributed to all mustahiq mentioned in At-Taubah verse 60 (Junaidi Abdillah, 2014: 28). The real impact of this paradigm is zakat only has a role to improve momentary consumption for Mustahiq. Therefore, a new breakthrough through a productive model is necessary in utilizing zakat for a broader benefits.

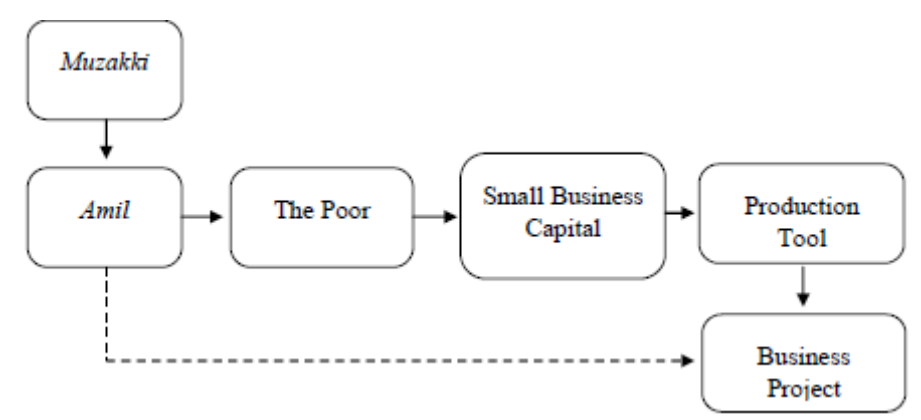

Figure 1. Economic empowerment model for the poor through small business capital program

There are two models of Baznas program in distributing zakat productively in economic empowerment of poor people in West Kalimantan, they are capital for small businesses and ZCD for poor village. Two models of zakat distribution based on the interviews with Drs. H. M. Basri Har, Vice Chairman IV of Administration, Human Resources and General Affairs at Baznas West Kalimantan Province.

Chronologically, Figure 1 explains that Muzakki pays zakat to Baznas West Kalimantan Province through Amil of Unit of Zakat Collector (UPZ) at Agency or Insitution and Task Force. After that, Baznas West Kalimantan Province distributed to mustahik by considering the feasibility study and complete fulfilled requirements. Subsequently, zakat given in the form of venture capital that can be used to buy tools for their business development. Baznas West Kalimantan Province conducts monitoring and evaluation to the project.

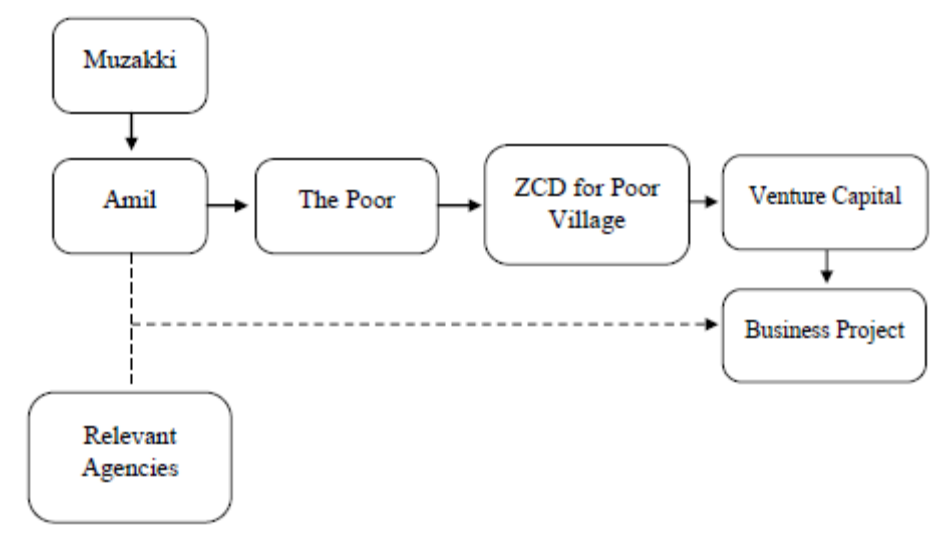

Figure 2. Economic empowerment model for the poor through ZCD program for poor village 
The sequence of Figure 2 is: Muzakki pays zakat to Baznas West Kalimantan Province through Amil of Unit of Zakat Collector (UPZ) at Agency or Institution and Task Force. After that, Baznas West Kalimantan Province distributed to mustahik by assessing the urgent needs and potency that can be developed in the village. Beforehand, Baznas West Kalimantan Province gathers the relevant agencies around the village to look for cooperation. Furthermore, Baznas West Kalimantan Province conducts monitoring and evaluation to the business project owned by mustahiq.

After doing the interview with Drs. H. M. Basri Har concerning economic empowerment for the poor through the National Board of Zakat (Baznas) West Kalimantan Province, in that case the writer suggests the revision of economic empowerment model for the poor in Baznas West Kalimantan Province using maqāsid al-syari'ah model as seen on Figure 3.

As specified by Figure 3, maqāsid al-syari'ah based model of economic empowerment for the poor through Baznas West Kalimantan Province is not much different from the preceding program. This model is a revision of the model that has been applied in Baznas West Kalimantan Province, its intention is zakat is going to be distributed productively to gain broader benefits.

Muzakkipays zakat to Baznas West Kalimantan Province through Amil of Unit of Zakat Collector (UPZ) at Agency or Insitution and Task Force. After that, Baznas West Kalimantan Province distributed to mustahik by considering the feasibility study, complete requirements, and potency of village and planned business project. After the venture capital distributed, Baznas West Kalimantan Province implements data collection, coaching, assistance and monitoring the business project of mustahik. In doing all aforementioned activities, Baznas West Kalimantan Province cooperates with the relevant agency around the residence of mustahik. The purpose is to make sure that the business is more optimal and it is able to be implemented in conformity with their expertise of respective business. Ultimately, Baznas West Kalimantan Province conducts evaluation to the business project of mustahik to be applied to the next mustahik.

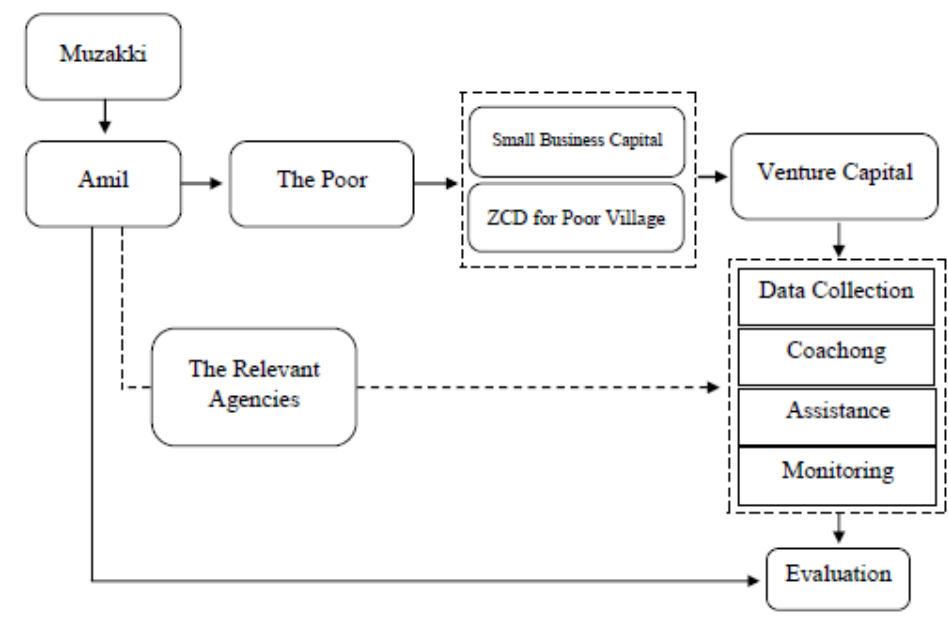

Figure 3. Maqāsid Al-Syari'ah based model of economic empowerment for the poor

\section{Summary}

Economic empowerment for the poor implemented by the National Board of Zakat (Baznas) West Kalimantan Province generally consists of two: the consumptive and productive model of economic empowerment for the poor. There are four obstacles faced by Baznas West Kalimantan Province in economic empowerment for the poor, they are lack of zakat funds collected by BAZNAS West Kalimantan Province from the existing potency, lack of operational funds, lack of human resources, and lack of endorsement from the relevant agencies in doing the economic empowerment for the poor.

Maqāsid al-syari'ah based model of economic empowerment for the poor through BAZNAS West Kalimantan Province is not much different from the preceding program.Muzakkipays zakat to Baznas West Kalimantan Province through Amil of Unit of Zakat Collector (UPZ) at Agency or Institution and Task Force. After that, baznas West Kalimantan Province distributed to mustahik by considering the feasibility study, complete 
requirements, and potency of village and planned business project. After the venture capital distributed, Baznas West Kalimantan Province implements data collection, coaching, assistance and monitoring the business project of mustahik by cooperating with the relevant agencies. Ultimately, Baznas conducts the evaluation to the business project of mustahik to be applied to the next mustahik.

\section{Reference}

Abdillah, Junaidi. (2014, February). Revitalisasi Amil Zakat Di Indonesia: Telaah atas Model-Model Kreatif Distribusi Zakat. dalam Jurnal Ijtimaiyya, 7(1).

Andriyanto, Irsad. (2014, December). Pemberdayaan Zakat DalamMeningkatkanKesejahteraan Umat. dalam Jurnal Zakat dan Infaq (ZISWAF), 1(2).

Antonio, M. S. (2001). Bank Syariah dari Teori ke Praktik. Jakarta: Gema Insani.

Anwar, Achmad Syaiful Hidayat. (2016, April). Model Pemberdayaan Ekonomi Mustahiq Melalui Zakat. dalam Jurnal (JEAM), XV.

Asmawi. (2012). Studi Hukum Islam; dari Tekstualis-Rasionalis Sampai Rekonsiliatif. Yogyakarta: Teras.

Aziz bin Baz, \& Syaikh Abdul. (2009). Zakat, e-Book dari Maktabah Raudhah al Muhibbin yang diterjemahkan dari on-line e-Book versi Bahasa Inggris dari situs. Retrieved from www.islamhouse.com

Beik, Irfan Syauqi, \& Arsyianti, Dwi Laily. (2016). Measuring Zakat Impact On Poverty And Welfare Using Cibest Model. Jurnal of Islamic Monetary Economics and Finance, 1(2).

Beik, Irfan Syauqi. (2009). Analisis Peran Zakat dalam Mengurangi Kemiskinan:Studi Kasus Dompet Dhuafa Republika. dalamJurnal Pemikiran dan Gagasan, II.

Chapra, M. Umer. (1999). Islam and the Economic Challenge, In Terj. Nurhadi Ihsan (Ed.), Islam dan Tantangan Ekonomi: Islamisasi Ekonomi Kontemporer. Surabaya: Risalah Gusti.

Fakhruddin. (2008). Fiqh \& Manajemen Zakat di Indonesia. Malang: UINMalang Press.

Hafidhuddin, Didin. (2004). Zakat Dalam Perekonomian Modern. Jakarta: Gema Insani Press.

Hendri, Nedi. (2015, November). Analisis Model-Model Pendayagunaan Dana Zakat Dalam Pemberdayaan Masyarakat Miskin Kota Di Provinsi Lampung. dalam Jurnal AKUISISI, 11(2).

Irmadariyani, Ririn dan Andriana, (2015). Model Pemberdayaan Zakat Produktif dalam Upaya Pengentasan Kemiskinan di Kabupaten Jember. dalam Executive Summary Penelitian Hibah Bersaing, Universitas Jember.

Karim, Adiwarman Azwar. (2010). Ekonomi Makro Islam. Jakarta: Rajawali Pers.

Karim, Adiwarman Azwar. (2010). Sejarah Pemikiran Ekonomi Islam. Jakarta: PT. Rajawali Press.

Kholiq, Abdul. (2012). Pendayagunaan Zakat, Infak dan Sedekah untuk PemberdayaanEkonomi Masyarakat Miskin Di Kota Semarang. dalam Jurnal Riptek, 6,(I).

Lihasanah, Ahsan. (2008). al-Fiqh al-Maqashid 'Inda al-Imami al-Syathibi. Mesir: Dar al-Salam.

Merriam, Sharan B. (2009). Qualitative Research, a Guide to Design andImplementation. San Fransisco: Jossey-Bass.

Nafik H.R., \& Muhammad dan Citra Aisya. (2016, March). Pemahaman Maqashid Syariah (Akal) Terhadap Kinerja Lembaga Zakat Yatim Mandiri Di Surabaya. dalam Jurnal Madania, et al/ Jurnal Ekonomi Syariah Teori dan Terapan, 3(3).

Ningrum, Ririn Tri Puspita. (2016, June). Penerapan Manajemen Zakat Dengan Sistem Revolving Fund Models Sebagai Upaya Efektifitas Penyaluran Zakat Produktif (Studi Pada Lembaga Manajemen Infaq Madiun). dalam Jurnal El-Wasathiya: Jurnal Studi Agama, 4(1).

Qadir, Abdurrahman. (1998). Zakat dalam Dimensi Mahdahdan Sosial. Jakarta: Raja Grafindo Persada.

Qardhawi ,Yusuf. (1993). Al-Ibadah Fi Al-Islam. Beirut: Muassasah al-Risalah.

Qardhawi ,Yusuf. (2011). Hukum Zakat (Studi Komparatif Mengenai Status danFilsafat Zakat Berdasarkan Qur'an danHadist). Bogor: Litera Antarnusa.

Qardhawi ,Yusuf. (2012). Fikih Maqashid Syari'ah. Jakarta: Pustaka al-Kautsar.

Rahman, Afzalur. (1995). Doktrin Ekonomi Islam Jilid I, Terj. Soeroyo, Nastangin Jakarta: Dana Bhakti Wakaf. 
Ramulyo, M. Idris. (2000). Hukum Perkawinan, Hukum Kewarisan Hukum Acara Peradilan Agama, dan Zakat Menurut Hukum Islam. Jakarta: Sinar Grafika.

Shirazi, N. S. (1996). Targeting, Coverage, and Contribution of Zakat to Household's Income. dalam Journal of Economic Cooperation among Islamic Countries.

Sudarti. (2011). Peranan Sektor Informal Dalam Penanggulangan Kemiskinan. dalam Jurnal Informasi, 16(03).

Sudarti. (2011, September). Modelpemberdayaan Masyarakat MiskinBerbasis IndustriKecil atau Kerajinan (IKK). dalam Jurnal HUMANITY, 7(1).

Sutikno, Eddy Setiadi Soedjono dkk. (2010, June). Pemilihan Program Pengentasan KemiskinanMelalui Pengembangan Model PemberdayaanMasyarakat Dengan Pendekatan Sistem. dalamJurnal Ekonomi Pembangunan, 11(1).

Syathibi. (2003). Al-Muawafaqat Fi Ushul al-Syari'ah. Juz I, Beirut: Dar al-Kutub al-Ilmiyah.

TIM Penulis UII. (2012). Pribumisasai Hukum Islam. Yogyakarta: Pps. FIAI UII.

Umar, Hasbi. (2007). Nalar Fiqih Kontemporer. Jakarta: Gaung Persada Press.

Wahyudi, Nur dan Ubaidillah. (2015). Penerapan Dana Zakat Produktif Terhadap Keuntungan Usaha Mustahik Zakat. dalam Jurnal Al-Mustashfa: Jurnal Penelitian Hukum Ekonomi Syariah, 3(2).

Yasin, Ahmad Hadi. (2012). Panduan Zakat Praktis. Jakarta: Dompet Dhuafa Republika.

Yin, Robert. K. (2009). Studi Kasus: Desain dan Metode. Jakarta: Raja Grafindo Persada.

Yunus, Mahmud. (1990). Kamus Arab-Indonesia. Jakarta: PT. Mahmud Yunus Wadzuryah.

Zuhayly, Wahbah. (2000). Al-Fiqh Al- Islami Adilatuh, Terj. Agus Efendi dan Bahruddin Fannany, Zakat Kajian Berbagai Mazhab, Cet. ke-5. Bandung: PT. Rosdakarya.

\section{Copyrights}

Copyright for this article is retained by the author(s), with first publication rights granted to the journal.

This is an open-access article distributed under the terms and conditions of the Creative Commons Attribution license (http://creativecommons.org/licenses/by/4.0/). 